SAL 30/2017

Tekstynais paremti vertimy kalbos tyrimai ir šaltiniai

Received 03/2017

Accepted 05/2017

Tekstynais paremti vertimų kalbos tyrimai ir šaltiniai

\title{
Corpus-Based Translation Studies: Research and Resources
}

\section{TRANSLATION /VERTIMAS}

\section{Jurgita Vaičenonienè}

Dr., lektorè, Vytauto Didžiojo universitetas, Lietuva.

\section{Jolanta Kovalevskaitè}

Dr., mokslo darbuotoja, Vytauto Didžiojo universitetas, Lietuva.

\section{Teresė Ringailienè}

Dr., lektorè, Vytauto Didžiojo universitetas, Lietuva.

\section{Г crossef http://dx.doi.org/10.5755/j01.sal.0.30.17693}

\section{Anotacija}

Tekstynais paremti vertimų kalbos tyrimai yra viena ryškiausių vertimo studijų krypčiu. Nors Lietuvoje kai kuriose srityse dominuoja vertimai, o ne originalūs lietuvių kalba rašyti tekstai, vertimų kalba kol kas dar nèra sulaukusi pakankamo Lietuvos tyrèju demesio. Tyrimu stoką gali lemti tai, kad iki šiol netureta reprezentatyviu lyginamuju vienakalbiu tekstynu, nors tekstynu lingvistikos metodas jau seniai taikomas ịvairiems lietuvių kalbos tyrimams. Atsižvelgiant i vertimu mastą rašytineje lietuvių kalboje šiame straipsnyje siekiama pagristi vertimu kalbos tyrimu svarbą Lietuvoje, apžvelgti šia tema atliktus darbus ir pristatyti lyginamaji vienakalbi tekstyną, sudarytą iš grožinès ir mokslo populiarinimo literatūros tekstu. Straipsnyje remiamasi deskriptyviuju vertimo studiju bei tekstynu lingvistikos tyreju darbais, taip pat paaiškinami pagrindiniai terminai, kai kurių terminu vertimai pateikiami pirmą kartą. Kuriamo lyginamojo originalios ir vertimy lietuvių kalbos tekstyno (ORVELIT) tikslas - reprezentuoti lietuviu vertimu kalbą leksinių-gramatiniu ir sintaksès ypatybiu tyrimams. Viso tekstyno apimtis apie $4 \mathrm{mln}$. žodžių; originaliosios ir vertimų kalbos grožinės literatūros ir mokslo populiarinimo kiekvieno iš patekstynių - apie $1 \mathrm{mln}$. žodžių. Atrenkant tekstus stengtasi subalansuoti tekstyną pagal kūriniu turinio, autoriu ir vertejju ivairovès, lyties, leidyklu ir chronologiniu remu kriterijus. Tikimasi, kad parengtas šaltinis paskatins gausesnius vertimu kalbos tyrimus, turès mokslinę ir praktinę vertę. ORVELIT lyginamuoju tekstynu bus galima naudotis kaip įrankiu, padedančiu suvokti tarpžanrinius tekstu reikalavimus ir ypatumus, atlikti tam tikru leksiniu vienetu paiešką, ¡vertinti vertimų ir originalių tekstų skirtumus.

REIKŠMINIAI ŽODŽIAI: lietuvių kalba, vertimu kalba, lyginamieji vienakalbiai tekstynai, tekstynais paremti vertimo tyrimai, vertimo universalijos, ORVELIT. 
Vertimo studijose teigiama, kad vertimai ne tik daro jtaką kalbai, bet ir yra savarankiška jos atmaina. Vertimai ir originalūs tos pačios kalbos tekstai gali būti suprantami kaip skirtingi registrai su jiems būdingomis ypatybèmis (Baker, 1993, 1995). Šis požiūris turètų būti ypač aktualus mažiau vartojamoms kalboms, kurios yra nuolat veikiamos dominuojančių kalbų. Lietuvai po Nepriklausomybès atgavimo tokią itaką daro anglu kalba. Iš šios kalbos verčiama daugiausia, o kai kuriose srityse iš anglu kalbos verčiama daugiau nei publikuojama lietuvišku tekstų. Pavyzdžiui, 2014-uju metu Lietuvos spaudos statistikos duomenimis, iš anglu kalbos išverstos knygos sudare net 63 \% visu vertimų. Be to, vertimu tiražas vidutiniškai dvigubai didesnis (1,9 tūkst. egz.) nei originalių knygu (1 tūkst. egz.), o tai rodo didesnę vertimu paklausą tarp skaitytoju; didžioji dalis vertimu (net 60 \%) yra grožinès literatūros kūriniai (Markevičienè ir Tamulynienè, 2015).

Lietuviškuose naujienu portaluose (pvz., užsienio, mokslo, pramogu, sporto ar kitu naujienų rubrikose) ir informaciniuose, mokslo populiarinimo bei pramoginiuose periodikos leidiniuose (pvz., A-ZET, National Geographic Lietuva, Cosmopolitan, Iliustruotasis mokslas ir kt.) nemažai informacijos yra verčiama iš ivairių užsienio šaltinių. Taigi galima daryti prielaidą, kad Lietuvoje grožinès literatūros ir mokslo populiarinimo leidiniuose vertimu pasiūla yra didesnè už originalią lietuvišką kūrybą. Būtent pramoginę grožinę ir jivairių sričių mokslo populiarinimo literatūrą lietuviškų leidyklų redaktoriai bei bibliotekų darbuotojai mini kaip daugiausia skaitomą (Lietuviu skaitymo ypatumai, 2015). Pateikti pavyzdžiai ne tik parodo vertimu ir originaliosios lietuvių kalbos santyki, bet ir pagrindžia šiu dviejų kalbos atmainų lyginamuju tyrimu poreiki ir svarbą.

Vertimu kalbos tyrimuose daugiausia dèmesio iki šiol skiriama didžiosioms kalboms, tokioms kaip anglu (Baker, 1993; Laviosa, 1997), vokiečiu (Kenny, 2001) ar kinu (Xiao et al., 2010), tačiau vis dar neaišku, ar didžiosiose kalbose nustatytos vertimų kalbos tendencijos būdingos ir tipologiškai skirtingoms mažosioms kalboms, pvz., lietuvių. Tekstynais paremti vertimu kalbos tyrimai yra viena ryškiausių krypčių moderniose vertimo studijose. Kita vertus, ši studiju ir tyrimu kryptis kol kas dar nèra sulaukusi pakankamo Lietuvos tyrejju dèmesio (Vaičenonienè, 2011; 2014). Tyrimų stoką gali lemti tai, kad, nors tekstynų lingvistikos metodai jau seniai taikomi jvairiems lietuvių kalbos tyrimams, iki šiol neturèta pakankamai reprezentatyvių lyginamuju vienakalbių tekstynų. Daugiakalbiuose lygiagrečiuosiuose tekstynuose reprezentuojama lietuvių kalba yra vertimų kalba, todèl trūko palyginamojo tekstyno, kuris galètų reprezentuoti ir vertimu, ir originalią lietuvių kalbą.

Atsižvelgiant i vertimu mastą rašytinèje lietuvių kalboje šiame straipsnyje siekiama trumpai aptarti tekstynais paremtu vertimo studiju raidą ir šaltinius, naudojamus vertimo kalbai tirti, vertimu kalbos tyrimus Lietuvoje. Straipsnyje taip pat pristatomas parengtas vienakalbis lyginamasis tekstynas, sudarytas iš grožinès ir mokslo populiarinimo literatūros tekstu (Lyginamasis originalios ir vertimy lietuviu kalbos tekstynas, toliau - ORVELIT). Straipsnyje remiamasi deskriptyviuju vertimo studiju bei tekstynu lingvistikos tyrejju darbais, taip pat paaiškinami pagrindiniai terminai, kai kurių terminų vertimai pateikiami pirmą kartą.

Vertimo studiju skiriamos dvi kryptys - teorinè (angl. Pure Translation Studies) ir taikomoji (angl. Applied Translation Studies) (Malmkjaer, 2012, p.31). Teoriniams tyrimams priskiriamos deskriptyviosios vertimo studijos (angl. Descriptive Translation Studies), kur atsiribojama nuo preskriptyviojo vertimu vertinimo ir skatinami sisteminiai, empirija paremti vertimu tyrimai (Toury, 1995; Malmkjaer, 2012). Deskriptyviuju vertimo studiju šakai priskiriamos ir tekstynais paremtos vertimo studijos (angl. Corpus Based Translation Studies). Šioje dalyje bandysime trumpai apžvelgti šios krypties raidą, užsienio ir lietuvių autorių darbus ir esamus šaltinius.

\section{Tekstynais paremti vertimu kalbos tyrimai ir šaltiniai}




\section{Vertimy kalbos tyrimai: vertimy} universalijos

Kitaip nei tradicinèse vertimo paradigmose, deskriptyviuosiuose vertimo tyrimuose nagrinejamas ne vertimo procesas, kai lyginamas originalas ir vertimas, bet analizuojamas ir apibūdinamas vertimo proceso rezultatas (Toury, 1995; Malmkjaer, 2012). Toks požiūris gali padèti išvengti išankstinių nuostatu dèl idealių, lūkesčių (ne)atitinkančių ekvivalentiškumo aspektu ir leidžia analizuoti vertimus kaip savarankiškus tekstus (Toury, 1995; Malmkjaer, 2012, p.34). Šios G. Toury'io (1995; 1995) idejos paskatino lyginamuosius ivairių žanru vertimų bei pačios vertimu kalbos tyrimus (Malmkjaer, 2012, p.34). Nors vertimų kalbos tyrimu būta ir anksčiau (pvz., Vanderauwera, 1985; Blum-Kulka, 1986), M. Baker (1993, 1995, 1996) juos ne tik apibendrino, bet ir viena pirmuju pasiūle tiriant vertimu kalbą taikyti tekstynu lingvistikos metodologiją, padèsiančią nustatyti vertimų kalbos ypatybes.

M. Baker teigimu, vertimai ne tik skiriasi nuo originalių tekstų, bet ir pasižymi universaliomis ypatybemis (Baker, 1993). Egzistuoja tam tikros vertimo kalbos universalijos - kalbos ypatybès, dažniau pasitaikančios verstuose, o ne originaliuose tekstuose, ir šios ypatybès nepriklauso nuo kalbos, iš kurios verčiama (Baker, 1993, p.243). M. Baker (1996) pasiūlè keturias tikètinas vertimu kalbos universalijas, kurias galima rasti lyginamuosiuose vienakalbiuose ivairiu kalbu tekstynuose: paprastinimas (angl. simplification), arba polinkis vartoti skurdesnę kalbą; eksplicitiškumas (angl. explicitation), arba polinkis i daugiažodžiavimą; norminimas (angl. normalization), arba polinkis paprastinti tai, kas vertimo kalbai neiprasta, perdètas vertimo kalbos normu laikymasis; neutralizavimas (angl. levelling out), arba polinkis vengti stilistiškai žymètos raiškos.

Nepaisant jvairiu diskusiju dè universaliju hierarchijos, tikslumo ir apibrěžčiu, per pastaruosius dvidešimt metu M. Baker idejjos ypač išpopuliarejo ir dabar pletojamos daugelio tyrejju darbuose, siekiant atrasti jvairiu kalbos ypatybių, kurios leistu pagristi vertimu kalbos universalijas (Laviosa, 1997, 1998; Kenny, 2001; Zanettin, 2013). Organizuojama tarptautiniu konferenciju šia tema (pavyzdžiui, Tarptautinès vertimo raštu ir kultūrinių studiju asociacijos (IATIS) 2004, 2006, 2009, 2012, 2015 m. konferenciju ciklas; R. Xiao organizuotos konferencijos, skirtos tekstynu taikymams lyginamosiose ir vertimo studijose (UCCTS 2010, 2012, 2013, 2014). Metodologiškai vertimu kalbos tyrimuose dažniausiai naudojami vienakalbiai lyginamieji ir dvikalbiai lygiagretieji ir (ar) lyginamieji tekstynai. Tyrejai pasirenka vieną ar kelias kalbos ypatybes, kuriu pasiskirstymo, dažnumo ir vartojimo palyginimas atskleidžia tos pačios kalbos originaliu ir verstu tekstų panašumus bei skirtumus. Dominuoja mažos apimties, t. y., vienos ypatybės, žanro ar universalijos tyrimai, o kompleksinių, didelės apimties, lyginamuju darbų nèra daug (pvz., Xiao et al., 2010).

Vis dèlto iš turimu tyrimu galima spręsti, kad vertimo proceso metu vertejai iš tikruju sąmoningai ir (ar) nesąmoningai paprastina kalbą, neperteikdami kūrybiškos raiškos, yra linkę laikytis tipiniu vertimo kalbai raiškos formy ar iterpti tikslinančios informacijos (Zanettin, 2012, p.13). Toliau aptarsime keletą dažniausia minimu darbų.

Atliekant lyginamuosius jivairių kalbų porų tyrimus ypač dažnai remiamasi S. Laviosos (1997, 1998) anglu vertimu kalbos tyrimais ir metodologija. Lygindama anglų vertimu kalbos tekstyno (angl. Translational English Corpus) ir Britu nacionalinio tekstyno (angl. British National Corpus) duomenis, S. Laviosa ištyrè, kad angliškuose vertimuose paprastinimas matyti iš mažesnès leksinès ivairovès, tankio ir informacinio svorio:

_ santykis tarp visų ir skirtingų teksto žodžių yra mažesnis nei originaliuose tekstuose;

_ dažnai vartojamų žodžių sąrašas yra ilgesnis, negu retai vartojamų žodžių;

_ dažni žodžiai vertimuose vartojami dažniau nei originaluose, taip pat turi mažiau lemų;

- prasminiu žodžių mažiau nei tarnybinių;

- vidutinis sakinio ilgis yra trumpesnis (nepasitvirtinusi hipotezè). 
Kinų kalbos tyrimas (Xiao et al., 2010) taip pat atskleidè, kad versti kinų kalbos tekstai pasižymi mažesne leksine ivairove. Kadangi kinu ir anglu kalbos tipologiškai labai tolimos, šie rezultatai ypač svarūs siekiant pagristi paprastinimo universaliją.

Eksplicitiškumo tyrimai (Olohan ir Baker, 2000) rodo, kad vertimams būdingos perteklinès sintaksinès struktūros, kurios vertimo kalboje paprastai būna pasirenkamos, o ne privalomos. Pavyzdžiui, pasirenkamas jungtukas that (liet. kad) po veiksmažodžiu say ir tell (liet. sakyti, pasakyti) dažnesnis vertimų nei originalioje anglu kalboje. Vertimuose i ispanų kalbą ¡vardžiai subjekto pozicijoje yra dažnesni, o originalioje ispanų kalboje - retesni (JiménezCrespo, 2011). Kita vertus, kai kurių tyrèjų nuomone, eksplicitiškumas turètų būti suprantamas ne kaip vertimo universalija, o kaip originalo kalbos ypatybiu perkèlimas ir itaka vertimo kalbai (plg. Saldanha, 2008).

Norminimo, dar kitaip vadinamo standartizavimo (Toury, 1995), tyrimais siekiama išsiaiškinti, ar ỉprasta, konvencinè, o ne kūrybinè raiška vertimuose pasirenkama dèl to, kad siekiama nenukrypti nuo vertimo kalbos normų. Remdamasi vokiečių literatūros vertimu i anglu kalbą tekstynu D. Kenny (2001) tikrino hipotezę, kad vertimuose neperteikiama kūrybinè raiška. Tyrimo rezultatai parodè, kad originale pavartoti kūrybiški žodžiai dažnai verčiami iprastais vertimo kalbai žodžiais ir frazemis. Kad leksiką linkstama versti neišlaikant originalo kūrybiškumo, rodo ir neiprastų kolokacijų vertimo analizè: galima matyti gana aiškų verteju polinki norminti neiprastus žodžiu junginius.

M. Baker pasiūlyta neutralizavimo universalija nesusilaukè tyreju dèmesio. Kita vertus, atsirado naujų vertimo universalijų siūlymu, pavyzdžiui, S. Trikkonen-Condit (2002) ir S. Eskola (2004) suformuluota unikalių kalbos vienetų stokos hipotezè (angl. translation of unique items). Autoriu teigimu, kalbos vienetai, kurie egzistuoja vertimo, o ne originalo kalboje, vertimams nebūdingi. Tyrimai parodè, kad suomiu kalbai būdingi leksiniai, sintaksiniai ir pragmatiniai konstruktai vertimuose iš anglu ir rusų kalbų pasitaikè rečiau nei originaliuose suomių kalbos tekstuose. K. Malmkjaer (2008, p.57) teigia, kad būtent ši hipotezè galètų būti laikoma perspektyviausia, nes atspindi kognityvinius sprendimus, o ne vertimo kalbos normų interferenciją, ir gali padèti pagristi, jog vertimu kalbos universalijos egzistuoja.

Universaliju tyrimų populiarumas lèmè ir terminų problemas: ta pati universalija gali būti suprantama plačiau ar siauriau, egzistuoja keli tą pati reiškini ivardijantys terminai, siūlomos naujos universalijos (pvz., perkèlimas (angl. transfer); unikalių kalbos vienetu stoka (angl. unique items); netipiniu kolokaciju vertimas (angl. untypical collocations); interferencija (angl. interference). F. Zanettinas $(2012,2013)$ parodo, kiek skirtingu pavadinimu yra vartojama toms pačioms universalijoms: pavyzdžiui, norminimą (angl. normalization) kiti autoriai vadina standartizavimu (angl. standardization), konservatizmu (angl. conservatism), konvencionalizacija (angl. conventionalization); eksplicitiškumas gali būti vadinamas asimetrija (angl. asymmetry). Nepaisant terminu variacijos ir diskusijų apie vertimų universalumą ar kaitą, priklausančią nuo tikslinės kalbos ir kultūros normų, tyrejai sutinka, kad vertimo kalba turi tik jai būdingu, savitu ypatybių, o šis požiūris skatina kuo ¡vairesnių kalbų porų ir krypčių tyrimus ir sudètingesnių, anotuotų tekstynų kūrimą.

Per pastaruosius dvidešimt metų Europoje ir JAV sukurta daugiau kaip šimtas ivairių tekstynų, skirtu vertimu tyrimams (Hu, 2016, p.9). Toliau apibendrinsime tik kai kuriuos dažniau minimus (pgl. Zanettin, 2012; Kruger et al., 2013; Hu, 2016) vertimų kalbos tyrimu šaltinius:

1 Atviros prieigos, vienakalbis, vienakryptis anglu vertimu kalbos tekstynas (Translational English Corpus (TEC)), pradetas kurti 1996 m. vadovaujant M. Baker. 10 mln. žodžiu teks-

Vertimy kalbos tekstynai

tyną sudaro angliški grožinès literatūros, laikraščiu kalbos, biografiniai ir skrydžio žurnalu tekstai, versti iš jivairių kalbu. Naudotas paprastinimo (pvz., Laviosa, 1997; 1998), eksplicitiškumo (Olohan ir Baker, 2000), standartizavimo (Olohan, 2004) universaliju tyrimams. 
2 Lygiagretusis, dvikryptis, morfologiškai anotuotas 2,6 mln. žodžiu grožinės ir negrožinės literatūros anglu-norvegu kalbu tekstynas (The English-Norwegian Parallel Corpus (ENPC), parengtas Oslo universitete (1994-1997) vadovaujant S. Johanssonui. 1997-2001 m. pridètos vokiečiu, olandu ir portugalu kalbos (Daugiakalbis Oslo tekstynas (Oslo Multilingual Corpus (OMC). Atlikti eksplicitiškumo (Ǿveras, 1998) tyrimai. Prieiga galima tik universiteto tyrejams.

3 Vienakalbis, lyginamasis suomiu vertimu kalbos tekstynas (The Corpus of Translational 3 Finnish (CTF)), sudarytas vadovaujant A. Mauraneen (2000). Tekstyną (9,6 mln. žodžiu) sudaro originali suomiu ir versta grožinè, vaiku, akademinè ir mokslo populiarinimo literatūra. Tyrinètos paprastinimo (Mauraneen, 2000), unikaliu kalbos vienetu (Trikkonen-Condit, 2002; Eskola, 2004) universalijos. Prieigos nèra.

/ Dorothy Kenny (2001) sudarytas dvikalbis, vienakryptis, lygiagretusis, šiuolaikinès gro4 žinès vokiečiu literatūros vertimu i anglu kalbą tekstynas (German English Parallel Corpus of Literary Texts (GEPCOLT)). Naudotas norminimo universalijos tyrimui. Tekstyno apimtis maždaug $2 \mathrm{mln}$. žodžių. Atviros prieigos nèra, neanotuotas.

5 Lygiagretusis, dvikryptis, 4,6 mln. žodžių, grožinès ir negrožinès literatūros anglų-italu vertimų tekstynas (English-Italian Translational Corpus (CEXI)), rengtas Bolonijos universitete, Forli, vadovaujant G. Aston. Tekstynas kurtas remiantis anglu-norvegu kalbu tekstyno (The English-Norwegian Parallel Corpus (ENPC)) sandaros principais. Projektas taip ir nebuvo baigtas nutrūkus finansavimui (Zanettin, 2012).

6 CroCo projekte (Linguistic Properties of Translations. A Corpus-Based Investigation for the O Language Pair English-German (CROCO)), 2005-2010 m. vykdytame Saarlando universitete (Hansen-Schirra et al., 2006) parengtas anotuotas, dvikalbis, dvikryptis, lygiagretusis, aštuoniu skirtingų registrų anglų-vokiečių kalbų tekstynas. 1 mln. žodžių tekstynas anotuotas gramatiškai, daugiausia tirtas vertimų eksplicitiškumo požiūriu (pvz., Hansen-Schirra et al., 2007).

7 Lankasterio universitete sudarytas lyginamasis kinu kalbos tekstynas (the Lancaster Corpus of Mandarin Chinese (LCMC)), kinu vertimu kalbos tekstynas (Xiao, 2010). Tekstyno apimtis - $1 \mathrm{mln}$. žodžiu, reprezentuojami jivairūs žanrai, anotuotas, laisvai prieinamas internete. Daug dèmesio skirta paprastinimo ir eksplicitiškumo tyrimams (Xiao et al., 2010).

Lygiagretusis, dvikryptis, anotuotas, tęstinis, $3 \mathrm{mln}$. žodžiu portugalu-anglų kalbų originalu 8 ir vertimu tekstynas (COMPARA: Portuguese - English Parallel Translation Corpus), sukurtas pagal anglu-norvegu kalbų tekstyno modeli (Frankenberg-Garcia et al., 2003). Tyrinètos paprastinimo ir eksplicitiškumo universalijos (pvz., Frankenberg-Garcia, 2009). Laisvai prieinamas.

Be pavyzdžiu, kurie jau išvardyti, dar kuriami lygiagretieji daugiakalbiai ar lyginamieji tekstynai kitoms kalbų poroms, pavyzdžiui, prancūzu-ispanu, anglu-rusu, anglu-slovènu, anglųlenku, etc. Nors egzistuoja nemažai resursų vertimu kalbos tyrimams, F. Zanettinas (2012, p.23) pastebi, jog susiduriama su tekstynų palyginamumo problemomis; mažosios kalbos ne visuomet turi pakankamai originalių ar verstų tam tikrų žanrų tekstų, kad būtų imanoma atitikti didžiujju kalbų tekstynų apimtis ir standartus; reikètų daugiau dėmesio skirti natūralios kalbos apdorojimo technologijoms ir tekstynu anotavimui; trūksta pakartotinu, lyginamuju skirtingų kalbų porų ir žanru, tarpdisciplininių tyrimų.

Tekstynais paremti vertimų tyrimai Lietuvoje
Lietuvoje taip pat gauseja vertimo studijoms skirtu darbu, kuriuose taikomi tekstynu ir kompiuterinès lingvistikos metodai. Galima skirti keletą tyrimu krypčiu. Visu pirma tai straipsniai, pristatantys jivairius šaltinius, tekstynus, ju kūrimo ir analizės principus, programinę irangą (pvz., Marcinkevičienè, 2002; Mikelionienè, 2002; Utka, 2004; Rimkutè et al., 2006, 2007, 2008; Utka et al., 2012). Žinoma, šiu darbu pritaikomumas apima daugeli skirtingu mokslo sričių, bet taip pat ypač svarbus ir galimiems vertimu kalbos tyrimams. 
Pavyzdžiui, VDU Kompiuterinès lingvistikos centre sukurti ir viešai prieinami lietuvių-latvių ir latvių-lietuviu kalbų lygiagretusis tekstynas (LILA) (Utka et al., 2012); dar anksčiau - dvikalbis lygiagretusis anglu-lietuvių, čeku-lietuvių kalbų tekstynas (Rimkutè et al., 2008),sudarytas iš tokių patekstynių:

- Anglų-lietuvių (70 813 lygiagretūs sakiniai; 2023005 žodžiai),

_ Lietuvių-anglu (1614 lygiagrečių sakinių; 61154 žodžiai),
Čekų-lietuvių (41 881 lygiagretus sakinys; 821479 žodžiai),

Lietuvių-čeku (693 lygiagretūs sakiniai; 21064 žodžiai).

Projektas nera baigtinis ir ateityje tekstyną planuojama pildyti naujomis kalbu poromis ir tekstais.

Antra, tai tyrimai, kuriuose tekstynai ir tekstynu lingvistikos metodai taikomi analizuojant tarpkalbinius raiškos skirtumus, vertimu atitikmenis leksikos, gramatikos, sintaksès, teksto rišlumo ar pragmatikos lygmenimis (Kaledaitè, 2006; Ruzaitè, 2010; Vaičenonienè, 2012). Naudojami jau sukurti, atviros prieigos, arba kuriami konkretaus tyrimo tikslams igyvendinti reikalingi tekstynai. Pavyzdžiui, S. Volungevičienès (2013) tyrimui apie kolokaciju vertimo iš vokiečių i lietuvių kalbą problemas sukurtas lygiagretusis vokiečių-lietuvių kalbų tekstų ir ju vertimų tekstynas (1 mln. žodžių), sudarytas iš jvairių kanceliarinių, administraciniu, grožinès literatūros ir populiariojo mokslo kūrinių bei ju vertimu. A. Šolienès (2013) disertacijoje „Episteminio modalumo ekvivalentiškumo parametrai anglų ir lietuvių kalbose“ duomenys išrinkti iš specialiai sukurto dvikalbio dvikrypčio lygiagrečiojo anglu-lietuvių kalbų tekstyno (1 572 $498 \mathrm{mln}$. žodžių), sudaryto iš originalių grožinès literatūros tekstų ir jų vertimų.

Trečia, mažiau tyreju dęmesio sulaukusi, tekstynais paremtu vertimu kalbos tyrimu kryptis. Pavyzdžiui, J. Vaičenonienès (2011) disertacijoje nagrinejjama leksikos standartizacija (norminimas) vertimuose. Sukurtame lygiagrečiajame grožinès lietuvių literatūros vertimu i anglu kalbą tekstyne (1 690164 mln., žodžių, 759841 lygiagrečių sakiniu) išrinkti ir analizuoti 166 stilistiškai žymèti okaziniai ir potenciniai žodžiai ir ju vertimai. Tyrimo rezultatai atskleidè, kad net $64 \%$ autorinių neologizmu vertimuose neišliko. Kita vertus, vertimo strategiju jvairove ir vertèjų požiūrio i tą pati vertimo vienetą skirtumai rodo, jog standartizacija yra daugiau tam tikra norma, kintanti priklausomai nuo kultūrinių, kalbiniu ar kitu faktorių, o ne universali vertimo kalbos ypatybe (plg. Kenny, 2001). Kitame tyrime (Vaičenonienè, 2014) aiškinamasi, kaip skiriasi originalu ir vertimų kalba neanotuotame lyginamajame grožinès literatūros tekstyne, sudarytame iš Dabartinés lietuvių kalbos tekstyno ir Lygiagrečiojo tekstyno duomenu. Originalios lietuvių literatūros patekstynio imtis - 6721 812, o vertimu iš anglu kalbos patekstynio - 2976425 žodžiai. Žodžiu dažnumo ir ivairovès, žodžiu sąrašų, prasminių ir tarnybinių žodžiu pasiskirstymas parodè, kad vertimu kalbos leksika yra ne tokia jivairi, jai būdingas paprastinimas. Ivardžių vartosenos analizè remia sintaksinio eksplicitiškumo universalijos idejją - vertimuose kai kurie ivvardžiai dažnesni negu originaliuose lietuviškuose kūriniuose.

Nors kuriami lygiagretūs ir lyginamieji tekstynai, šių tekstynų apimtis gana ribota, dalis ju viešai neprieinami, neanotuoti. Tekstynu kūrimo kriterijai skiriasi, o tai neleidžia atlikti lyginamuju tyrimu. Dominuoja grožinès literatūros vertimu tekstynai ir tyrimai, ypač iš (i) anglų kalbą, trūksta tarpžanriniu studiju. Kita vertus, kaip jau minèta anksčiau, tokios duomenu gausos, nesuderinamumo, prieigos ir saugojimo problemos bendros ir kitu šaliu vertimo studijoms, ieškoma būdu joms spręsti (Zanettin, 2012).

Lyginamieji tekstynai gali būti vienakalbiai, dvikalbiai ar daugiakalbiai, ju lyginamąsias dalis sudaro tais pačiais kriterijais (pvz., teksto dydžio, turinio, laikotarpio ir kt.) atrinkti tekstai, vienodai ar panašiai reprezentuojantys pasirinktą kalbos atmainą vienoje ar keliose kalbose (Olohan, 2004; Kenning, 2010). Pavyzdžiui, gali būti kuriami lyginamieji daugiakalbiai lai-

\section{ORVELIT}


kraščiu, politikos, darbo skelbimu tekstynai (Kenning, 2010, p.487) arba vienakalbiai originalu ir vertimu tekstynai (Olohan, 2004, p.35). ORVELIT yra vienakalbiu lyginamuju tekstynu tipui priskirtinas tekstynas.

M. Nelsonas (2010, p.54) atkreipia dèmesi, kad prieš kuriant naują tekstyną, svarbu ivertinti jo poreiki, naujumą ir svarbą. Kadangi lyginamojo vertimu ir originalu tekstyno lietuviu kalbai iki šiol nebuvo, ORVELIT poreikis yra pagristas. Kuriamo tekstyno tikslas - reprezentuoti lietuvių vertimų kalbą leksinių-gramatinių ir sintaksės ypatybių tyrimams. Tekstyno sandara leis tirti vertimo kalbos ypatybes dviejuose, grožinès literatūros ir mokslo populiarinimo, registruose. Svarbu pabrěžti, kad šiuo tekstynu siekiama atspindèti vertimu iš anglu kalbos ypatumus, o ne reprezentuoti lietuvių grožinę ar mokslo populiarinimo literatūrą apskritai.

Kuriant ORVELIT tekstyną vadovautasi principais, kurie pateikiami duomenu tvarkybos planuose (angl. Data Management Plan) ir yra svarbūs kuriamu kalbos išteklių ilgalaikiškumui, sklaidai ir prieinamumui užtikrinti. Duomenų tvarkybos planuose išskiriami tokie žingsniai:

1 Duomeny rinkimo sprendimai (pvz., duo-

menu pobūdis, kiekis, prieinamumas, saugojimo formatas, ilgalaikiškumas, taikomi standartai, metodologijos, metaduomeny standartai ir kt.).

2 Dokumentacijos ir metaduomenu sprendimai (duomenu rinkimo, klasifikacijos, pobūdžio ir t. t. aprašymas reikalingas ateities tyrimams; egzistuojančiu metaduomenu aprašymo standartų taikymas/ adaptavimas - tyrimo tikslams).

3 Etikos ir teisiniai sprendimai (duomeny 3 rinkimo, saugojimo, platinimo, anonimiškumo užtikrinimo, autorinių teisių klausimai).

Pareigos ir resursai (ištekliaus kūrimo ir saugojimo biudžetas, darbu paskirstymas ir kt.) (Trippel ir Zinn, 2015, p.71).

ORVELIT tekstynui taikytas Europos moksliniu tyrimy infrastruktūros humanitariniams ir socialiniams mokslams, skirtos kalbos ištekliams (duomenims ir irankiams) CLARIN ERIC siūlomas duomenu tvarkybos plano vediklis (CLARIN-D).

Kuriant vertimu kalbos tekstynus vadovaujamasi panašiais kūrimo principais kaip ir sudarant bet kuriuos kitus tekstynus (Zanettin, 2012, p.47). Tam, kad būtu atspindètos vertimu kalbos ypatybès, tekstynas turètu būti pakankamai didelis, subalansuotas, patekstynius sudarytu pakankamai tekstų, kurie reprezentuotų kalbų, autorių, leidejju, autorių ir verteju jivairovę (Zanettin, 2012, pp.47-48). Toliau aptarsime grožinès literatūros ir mokslo populiarinimo patekstynių sandarą.

ORVELIT susideda iš keturiu patekstyniu, kuriu ryšiai gali būti vaizduojami 1 paveiksle.

Teoriškai grožinès literatūros vertimu patekstyni galima būtu lyginti su esamo Dabartinès lietuviu kalbos tekstyno (DLKT) grožinès literatūros patekstyniu, kuris atspindi skirtingu laiko-

\section{1 paveikslas}

ORVELIT patekstyniu palyginamumas


tarpių, kartų, lyčiu, žanrų ir kt. literatūrą. Kita vertus, kadangi vertimu literatūros patekstynio turinys daug siauresnis, kyla klausimas, ar palyginimas būtu validus. Be to, DLKT grožinès literatūros dalyje gali būti tiek originaliu, tiek verstu kūrinių, rašytu gimtakalbiu ir negimtakalbių, išeivijos atstovų, itraukti atsiminimai ar kiti žanrai. DLKT yra ir negrožinès literatūros dalis, kurioje be mokslo populiarinimo tekstu yra ir mokslo, mokomosios, pažintinès literatūros tekstai, taigi ši dalis taip pat negali būti laikoma palyginama mokslo populiarinimo pa- 
tekstyniui. Dèl to nuspręsta iš DLKT esančių duomenu sukurti atskirus originalios grožinès ir mokslo populiarinimo literatūros patekstynius, kurie savo sandara būtų kuo panašesni i vertimu kalbos patekstynius ir reprezentuotu ne grožinę ir mokslo populiarinimo literatūrą apskritai, bet originalią lietuvių kalbą.

Viso ORVELIT tekstyno apimtis - 4034347 mln. žodžių; originaliosios ir vertimu kalbos grožinès literatūros ir mokslo populiarinimo patekstyniu - daugiau nei $1 \mathrm{mln}$. žodžių. Tokio dydžio imtis laikoma pakankama tyrinejjant didelio dažnumo gramatines, leksines ypatybes ir specializuotus žanrus (Evison, 2010, p.123). Tekstyną sudaro kūriniai (visateksčiai), išsaugoti .txt formatu, ANSI (American National Standards Institute) koduote. Žodžiu skaičiui nustatyti naudota WordSmith Tools 7.0 (Scott, 2016) versija. Atrenkant tekstus stengtasi subalansuoti tekstyną pagal kūriniu turinio, autoriu ir verteju jvairovès, lyties, leidyklu ir chronologiniu rẻmų kriterijus (žr. 1 lentelę). Kai kurie sprendimai, pavyzdžiui, dèl chronologinių tekstyno

\begin{tabular}{|c|c|c|c|c|}
\hline Kriterijus & $\begin{array}{l}\text { Grožinès litera- } \\
\text { tūros vertimu } \\
\text { patekstynis }\end{array}$ & $\begin{array}{l}\text { Originalios gro- } \\
\text { žinès literatūros } \\
\text { patekstynis }\end{array}$ & $\begin{array}{l}\text { Mokslo populia- } \\
\text { rinimo vertimų } \\
\text { patekstynis }\end{array}$ & $\begin{array}{c}\text { Originalios mokslo } \\
\text { populiarinimo litera- } \\
\text { tūros patekstynis }\end{array}$ \\
\hline Tipas & \multicolumn{4}{|c|}{ Specializuotas, lyginamasis, vienakalbis, vienakryptis } \\
\hline Reprezentatyvumas & $\begin{array}{l}\text { Anglų kalbos gro- } \\
\text { žinès literatūros } \\
\text { vertimų kalba }\end{array}$ & $\begin{array}{l}\text { Lietuvių grožinės } \\
\text { literatūros kalba }\end{array}$ & $\begin{array}{l}\text { Anglu kalbos moks- } \\
\text { lo populiarinimo } \\
\text { tekstų vertimų kalba }\end{array}$ & $\begin{array}{l}\text { Lietuvių mokslo } \\
\text { populiarinimo tekstų } \\
\text { kalba }\end{array}$ \\
\hline Populiacija & $\begin{array}{l}\text { Grožinè literatūra, } \\
\text { versta iš anglų } \\
\text { kalbos }\end{array}$ & $\begin{array}{l}\text { Originali grožinė } \\
\text { lietuvių literatūra }\end{array}$ & $\begin{array}{l}\text { Mokslo populiarini- } \\
\text { mo literatūra, vers- } \\
\text { ta iš anglu kalbos }\end{array}$ & $\begin{array}{l}\text { Originali lietuvių kalba } \\
\text { rašyta mokslo popu- } \\
\text { liarinimo literatūra }\end{array}$ \\
\hline Imties rèmai & $\begin{array}{l}\text { Dabartinès lietuviu } \\
\text { kalbos tekstyno } \\
\text { grožinės literatū- } \\
\text { ros dalis; Lygia- } \\
\text { grečiojo tekstyno } \\
\text { vertimu dalis }\end{array}$ & $\begin{array}{l}\text { Dabartinés lietuvių } \\
\text { kalbos tekstyno } \\
\text { grožinės lietuvių } \\
\text { literatūros dalies } \\
\text { kūriniai, rašyti } \\
\text { lietuvių autorių }\end{array}$ & $\begin{array}{l}\text { Dabartinès lietuviu } \\
\text { kalbos tekstyno ne- } \\
\text { grožinès literatūros } \\
\text { dalis; Lygiagrečiojo } \\
\text { tekstyno vertimy } \\
\text { dalis }\end{array}$ & $\begin{array}{l}\text { Dabartinès lietuvių } \\
\text { kalbos tekstyno } \\
\text { negrožinès literatūros } \\
\text { dalies kūriniai, rašyti } \\
\text { lietuvių autorių }\end{array}$ \\
\hline Imties vienetas & \multicolumn{4}{|c|}{ Knyga tekstinio failo formatu } \\
\hline Žodžių skaičius & $\begin{array}{l}1003747 \text { mln. } \\
\text { žodžių }\end{array}$ & $\begin{array}{l}1003519 \text { mln. } \\
\text { žodžių }\end{array}$ & $\begin{array}{l}1010830 \mathrm{mln} . \\
\text { žodžių }\end{array}$ & $\begin{array}{l}1016251 \text { mln. } \\
\text { žodžių }\end{array}$ \\
\hline Tekstų skaičius & $\begin{array}{l}18 \text { visateksčių } \\
\text { kūrinių }\end{array}$ & $\begin{array}{l}18 \text { visateksčių } \\
\text { kūrinių }\end{array}$ & $\begin{array}{l}19 \text { visateksčių } \\
\text { kūrinių }\end{array}$ & $\begin{array}{l}25 \text { visateksčiai } \\
\text { kūriniai }\end{array}$ \\
\hline Pobūdis & $\begin{array}{l}\text { Rimtoji ir } \\
\text { populiarioji } \\
\text { literatūra }\end{array}$ & $\begin{array}{l}\text { Rimtoji ir } \\
\text { populiarioji } \\
\text { literatūra }\end{array}$ & $\begin{array}{l}\text { Humanitarinių, } \\
\text { socialiniu, } \\
\text { ekonomikos } \\
\text { mokslų, medicinos } \\
\text { populiarinimas }\end{array}$ & $\begin{array}{l}\text { Humanitariniu, socia- } \\
\text { linių, gamtos ir eko- } \\
\text { nomikos, informaciniu } \\
\text { technologijų, medicinos } \\
\text { mokslų populiarinimas }\end{array}$ \\
\hline Autoriai & $\begin{array}{l}18 \text { skirtingu } \\
\text { autorių }\end{array}$ & $\begin{array}{l}18 \text { skirtingu } \\
\text { autorių }\end{array}$ & $\begin{array}{l}19 \text { skirtingu } \\
\text { autorių }\end{array}$ & $\begin{array}{l}24 \text { skirtingi } \\
\text { autoriai }\end{array}$ \\
\hline Lytis & 8 moterys, 10 vyru & 9 moterys, 9 vyrai & 7 moterys, 16 vyru & 15 moteru, 19 vyru \\
\hline Vertejai & 15 skirtingų vertèju & - & 19 skirtingu vertèju & - \\
\hline Leidyklos & $\begin{array}{l}12 \text { skirtingu } \\
\text { leidyklų }\end{array}$ & $\begin{array}{l}5 \text { skirtingos } \\
\text { leidyklos }\end{array}$ & $\begin{array}{l}6 \text { skirtingos } \\
\text { leidyklos }\end{array}$ & $\begin{array}{l}10 \text { skirtingu } \\
\text { leidyklų }\end{array}$ \\
\hline $\begin{array}{l}\text { Chronologiniai } \\
\text { vertimų rémai }\end{array}$ & $1981-2011$ & - & 2005-2012 & - \\
\hline $\begin{array}{l}\text { Chronologiniai } \\
\text { kūrinių rèmai }\end{array}$ & 1952-2006 & 1994-2012 & 1963-2011 & 2005-2012 \\
\hline
\end{tabular}

\section{1 lentelé}

Vertimu ir originalu patekstyniu sandara 
rèmu, buvo nulemti ribotos Lygiagrečiojo ir Dabartinés lietuviu kalbos tekstynų imties, t. y., norint išlaikyti pakankamą autorių, vertejjų ir temu ivairovę, nuspręsta įtraukti ne tik šiuolaikinę literatūrą, bet ir kūrinius, rašytus nuo XX a. vidurio.

Pastebejjome, kad ypač problemiškas kriterijus yra lyčių balansas: nors grožinès literatūros patekstynyje vyru ir moteru autoriu skaičius - apylygis, mokslo populiarinimo patekstynyje taikyti ši kriteriju buvo sudètingiau, nes kūrinių pasirinkimo galimybės buvo ribotesnès: imties rèmuose prieinami kūriniai turèjo atitikti mokslo populiarinimo žanro apibrěžimą, o tai susiaurino ir temu jvairovę.

Pats mokslo populiarinimas gali būti suprantamas keleriopai. Anot Burns ir kt. (2003), tai gali būti ir visuomenès susidomejjimas mokslu, o kartais šis terminas vartojamas tiesiog kalbant, kaip visuomenè supranta mokslą, mokslinę kultūrą ir raštingumą. Sudarant mokslo populiarinimo patekstyni, laikytasi pačios bendriausios sampratos: jvairių žanru tekstai, kuriuose specializuotas mokslas transformuojamas taip, kad ji suprastų nespecialistai; kitaip tariant, mokslu siekiama sudominti nespecialistus (Calsamiglia ir van Dijk, 2004).

Taigi dèl mokslo populiarinimo patekstynio laikytasi nuostatos, kad lyties kriterijus ne toks svarbus kaip temu jvairovè. Ir mokslo populiarinimo vertimu, ir originaliosios mokslo populiarinimo literatūros patekstyni sudaro humanitarinių, socialinių, ekonomikos, medicinos mokslu populiarinimo tekstai. Kai kurios sritys, pavyzdžiui, informaciniu technologiju ar gamtos mokslų, būdingos tik originaliai mokslo populiarinimo daliai. Kitaip nei grožinès literatūros patekstynyje, mokslo populiarinimo dalyje kai kurie tekstai rašyti dvieju ar daugiau autorių, o tai irgi atskleidžia skirtingu žanru ypatumus. Nors tekstyne ir nepavyko išlaikyti vienodo balanso tarp visų išskirtu atrankos kriteriju, manome, kad tai nèra didelis trūkumas. Viena vertus, esama sudetis atskleidžia realią rašomų tekstų situaciją, kita vertus, tekstynai nebūtinai yra baigtiniai ar išaldyti. Kiekvienas tyrejjas gali modeliuoti ir koreguoti tekstyno turini ir apimti pagal savo tyrimo tikslus.

Pirmoji tekstyno versija, planuojama, bus saugoma Lietuvos nacionalinio konsorciumo CLARIN-LT' centro saugykloje. Prieiga prie tekstyno bus galima su riboto naudojimo pobūdžio (RES) licencija, kuri apibrezžia naudotojo tapatybės ir prieigos sąlygas, bendrąsias naudojimo ir platinimo sąlygas (Teisine CLARIN-LT veiklos studija, 2015, pp.29-30). Be visateksčiu dokumentų, tyrejams gali būti pateikiami ir tokie duomenys kaip dažninių žodžių sąrašai, metaduomenys ir kita tyrimams aktuali informacija.

Sudarant tekstyną buvo vadovautasi teisinès CLARIN-LT veiklos studijoje (2015) pateiktu išaiškinimu dèl kuriamy ištekliu autorinių teisių, kurioje teigiama, kad CLARIN-LT saugomi duomenys, o tai reiškia ir tekstynai, nepažeidžia autorinių teisių, numatytu pagal Lietuvos Respublikos autorinių teisių ir gretutiniu teisiu istatymą:

CLARIN-LT turinys - autorinio turinio nedidelès dalys nurodant šaltini, kūriniai (net visateksčiai) moksliniais arba informaciniais tikslais - gali būti naudojami be originalaus autoriaus (teisių turètojo) žinios, be leidimo ir be atskiro atlyginimo (Teisine CLARIN-LT veiklos studija, 2015, p.23). Sudarant ORVELIT tekstyną visi tekstai buvo pernaudoti iš DLKT ir Lygiagrečiojo tekstynu, dèl to nereikejo iš naujo spręsti autorinių teisių klausimu.

1 CLARIN-LT yra Bendrosios kalbos ištekliu ir technologiju infrastruktūros CLARIN ERIC B tipo centras. Viena CLARIN-LT siūlomy paslaugu yra duomenų saugojimas, kuriuo siekiama užtikrinti šaltinių, tekstynu, programinès įrangos ir kitokių duomenų ilgaamžiškumą, prieigą, vienodus socialinių ir humanitarinių mokslų duomenų kūrimo standartus ir kokybę. 
Nors atlikta nemažai tyrimų ir rasta ¿vairiu vertimo kalbos ypatybes liudijančių ¿̇rodymų, daugiausia tiriamos didžiosios kalbos, todèl ypač skatinami ir reikalingi mažiau paplitusių, ivairesnių kalbų ir ju poru tyrimai. Taip pat reikètu pastebèti, kad dominuoja literatūros vertimu tyrimai, tuo tarpu kitiems žanrams ar ju lyginimui skiriama mažiau dèmesio. Taigi tarpžanrinis vertimo ypatybių tyrimas leistu objektyviau ivertinti ju paplitimą ir universalumą.

Manoma, kad sukurto naujo tekstyno ORVELIT, kuri ateityje numatoma morfologiškai ir sintaksiškai anotuoti bei suteikti atvirą prieigą, tyrimu rezultatai tures ne tik mokslinę, bet ir praktinę vertę ruošiant profesionalius jvairių sričių vertèjus, filologus. ORVELIT lyginamuoju tekstynu bus galima naudotis kaip įrankiu, padedančiu suvokti tarpžanrinius tekstu reikalavimus ir ypatumus, atlikti tam tikrų leksinių vienetu paiešką, jvertinti vertimų ir originaliu tekstu skirtumus. Tekstynas bus naudingas ir vertimo studiju ar filologijos dėstytojams kaip pagalbinè priemonè ruošiant mokymo užduotis. Gautos išvados apie vertimu kalbos ypatybes palengvins profesionaliu verteju, kalbos redaktoriu darbą, padès objektyviai vertinti vertimu kokybę. Taip pat tikimasi, kad bus paskatinti tolimesni tyrimai, ¿traukiantys vertimus iš skirtingu kalbu grupių, analizuojantys specializuotų originaliu ir verstu tekstu, pavyzdžiui, teisinès ar techninès kalbos, ypatumus, kuriami ne tik lyginamieji, bet ir lygiagretūs ar multimodalūs tekstynai, skirti ne tik rašytinei, bet ir sakytinei vertimo kalbai.
1. Advokatų profesinè bendrija FORT, 2015. Teisine CLARIN-LT veiklos studija. Vilnius.

2. Baker, M., 1993. Corpus Linguistics and Translation Studies: Implications and Applications. Francis, G., and Tognini-Bonelli, E., eds., Text and Technology: Honour of John Sinclair Amsterdam/ Philadelphia: John Benjamins, pp.233-250.

3. Baker, M., 1995. Corpora in Translation Studies. An Overview and Some Suggestions for Future Research. Target, 7 (2), pp.223-243. https://doi.org/10.1075/target.7.2.03bak

4. Baker, M., 1996. Corpus-based Translation Studies - the Challenges that Lie Ahead. In: Somers, H., ed., Terminology, LSP and Translation. Philadelphia/ Amsterdam: John Benjamins, pp.175-86. https://doi.org/10.1075/ btl.18.17bak

5. Blum-Kulka, S., 1986. Shifts of Cohesion and Coherence in Translation. In: House, J., Blum-Kulka, S., Interlingual and Intercultural Communication. Discourse and Cognition in Translation and Second Language Acquisition. Tübingen: Günter Narr Verlag, pp.17-35.

6. Burns, T. W., O'Connor, D. J., Stocklmayer, S. M., 2003. Science Communication: A Contemporary Definition. Public Understanding of Science 12 (183), pp.183-202. Prieiga per internetą: http://journals.sagepub.com/doi/ abs/10.1177/09636625030122004 [Žiūrèta 2016 m. gruodžio mèn].

7. Calsamiglia, H., van Dijk, T., 2004. Popularization Discourse and Knowledge about the Genome. Discourse and Society 15 (4), pp.369-389. https://doi. org/10.1177/0957926504043705

8. Eskola, S., 2004. Untypical Frequencies in Translated Language: A Corpus-based Study on Literary Corpus of Translated and Non Translated Finnish. In: Mauraneen, A., Kujamäki, eds., Translation Universals. Do they Exist? Amsterdam/ Philadelphia: John Benjamins, pp.83-99. https://doi.org/10.1075/btl.48.08esk

9. Evison, J., 2010. What are the Basics of Analysing a Corpus? In: O'Keeffe, A., McCarthy, M., The Routledge Handbook of Corpus Linguistics. London/ New York: Routledge, pp.122-135. https://doi.org/10.4324/9780203856949.ch10

10. Frankenberg-Garcia, A., Santos, D., 2003. Introducing COMPARA, the PortugueseEnglish Parallel Translation Corpus. In: Zanettin, F., Bernardini, S., Stewart, D., eds., Corpora in Translation Education. Manchester: St. Jerome Publishing, pp.71-87. Prieiga per internetą: http://citeseerx.ist.psu.edu/viewdoc/ download?doi=10.1.1.13.7050\&rep=rep1\& type=pdf [Žiūrèta 2016 m. liepos mèn.] 
11. Frankenberg-Garcia, A., 2009. Are Translations Longer that Source Texts? A Corpus-based Study of Explicitation. In: Beeby, A., Rodriguez, P., Sanchez-Gijon, P. (eds.), Corpus Use and Translating. Amsterdam/ Philadelphia: John Benjamins, pp.47-58. https://doi. org/10.1075/btl.82.05fra

12. Hansen-Schirra, S., Neumann, S., Vela, M., 2006. Multi-dimensional Annotation and Alignment in an English-German Translation Corpus. Proceedings of the Workshop on Multi-dimensional Markup in Natural Language Processing, EACL, pp.35-42. https:// doi.org/10.3115/1621034.1621040

13. Hansen-Schirra, S., Neumann, S., Steiner, E., 2007. Cohesive Explicitness and Explicitation in an English-German Translation Corpus. Information Structuring Resources in Contrast, Languages and Contrast, 7(2), pp.241-265.

14. Hu, K., 2016. Introducing Corpus-based Translation Studies. Heidelberg/ New York: Springer, $p$. 9. https://doi.org/10.1007/978-3-662-48218-6

15. International Association for Translation and Cultural Studies. Prieiga per internetą: http:// www.iatis.org/index.php/iatis-belo-horizonteconference [Žiūrèta 2016 m. liepos mèn.].

16. Jiménez-Crespo, M. A., 2011. The Future of General Tendencies inTranslation: Explicitation in Web Localization. Target, 23(1), pp.3-25. https://doi.org/10.1075/target.23.1.01jim

17. Kalèdaitè, V., 2006. Translating Existence (A Corpus-based Analysis). Darbai ir Dienos, 45, pp.119-125.

18. Kenning, M. M., 2010. What are Parallel and Comparable Corpora and How Can We Use Them? In: O'Keeffe, A., McCarthy, M., eds. The Routledge Handbook of Corpus Linguistics. London/ New York: Routledge, pp.487-500. https://doi.org/10.4324/9780203856949.ch35

19. Kenny, D., 2001. Lexis and Creativity in Translation. A Corpus-based Study. Manchester: St Jerome.

20. Kruger, A., Wallmach, K., Munday, J., 2013. Corpus-Based Translation Studies. Research and Applications. London/ New York: Bloomsbury.

21. Laviosa, S., 1997. How Comparable Can Comparable Corpora Be? Target, 9(2), pp.289-319. https://doi.org/10.1075/target.9.2.05lav
22. Laviosa, S., 1998. Core Patterns of Lexical Use in a Comparable Corpus of English Narrative Prose. Meta 43 (4), pp.557-570. https://doi. org/10.7202/003425ar

23. Lietuvių skaitymo ypatumai, 2015. Veidas. [prieiga internetu] http://www.veidas.lt/ lietuviu-skaitymo-ypatumai. [Žiūrèta 2016 m. liepos mèn.]

24. Lietuvos Respublikos autoriniu teisių ir gretutinių teisių istatymas. Prieiga per internetą: https://www.etar.lt/portal/lt/legalAct/ TAR.551F0CDE5B64/UMOLkJpCuL [Žiūrèta $2016 \mathrm{~m}$. liepos mèn.].

25. Malmkjaer, K., 2008. Norms and Nature in Translation Studies. In: Anderman, G., Rogers, M., eds., Incorporating Corpora - Corpora and the Translator. Clevedon: Multilingual Matters, pp.49-59.

26. Malmkjaer, K., 2012. Where Are We? (From Holme's Map until Now). The Routledge Handbook of Translation Studies. London/ New York: Routledge, pp.31-44.

27. Marcinkevičienè, R., 2002. Palyginamieji tekstynai - šaltinis tarptautinių žodžių vartosenai tirti. Kalbotyra, 51 (3), pp.81-93.

28. Markevičienè, R., Tamulynienè, L., 2015. Lietuvos spaudos statistika. Vilnius: Lietuvos nacionalinè Martyno Mažvydo biblioteka.

29. Mauraneen, A., 2000. Strange Strings in Translated Language. A Study on Corpora. In: Olohan, M.(ed.) Intercultural Faultlines. Manchester: St Jerome Publishing, pp.119-141.

30. Mikelionienè, J., 2002. Palyginamojo tekstyno kūrimo principai, problemos ir panaudojimo galimybès. Kalbu studijos, 3, Kaunas: Technologija, pp.55-59.

31. Nelson, M., 2010. Building a Written Corpus. What are the Basics? The Routledge Handbook of Corpus Linguistics. London/ New York: Routledge, pp.53-65.

32. Olohan, M., Baker, M., 2000. Reporting That in Translated English: Evidence for Subconscious Processes of Explicitation? Across Languages and Cultures, 1(2), pp.141-158. https://doi. org/10.1556/Acr.1.2000.2.1

33. Olohan, M., 2004. Introducing Corpora in Translation Studies, London/ New York: Routledge. 
34. Øverås, L., 1998. In Search of the Third Code: An Investigation of Norms in Litarary Translation. Meta, 43(4), pp.557-570. https://doi. org/10.7202/003775ar

35. Rimkute, E., Kovalevskaitè, J., Daudaravičius, V., 2006. Daugiakalbių tekstynų naudojimas ir taikymas. Darbai ir Dienos, 45, pp.41-62.

36. Rimkute, E., Daudaravičius, V., 2007. Morfologinis Dabartinès lietuvių kalbos tekstyno» anotavimas. Kalbų studijos, 11, pp.30-35.

37. Rimkute, E., Daudaravičius, V., Utka, A., Kovalevskaitè, J., 2008. Bilingual Parallel Corpora for English, Czech and Lithuanian. Proceedings of The Third Baltic Conference on Human Language Technologies 2007, pp.319-326.

38. Ruzaitè, J., 2010. Translation Equivalents of Vague Language Items: a Study of General Extenders in a Parallel Corpus. Kalbu studijos, 16, pp.33-38.

39. Saldanha, G., 2008. Explicitation Revisited: Bringing the Reader into the Picture. In: House, J., Beyond Intervention: Universals in Translation Process, trans-kom 1(1), pp.2035. Prieiga per internetą: http://www.transkom.eu/bd01nr01/trans-kom_01_01_03_ Saldanha_Explicitation.20080707.pdf [Žiūrèta 2016 m. liepos mèn.].

40. Scott, M., 2016. WrodSmith Tools. Prieiga per internetą: http://www.lexically.net/ wordsmith/ [Žiūrèta 201607 31].

41. Šolienè, A., 2013. Episteminio modalumo ekvivalentiškumo parametrai anglų ir lietuvių kalbose. (Daktaro disertacija).Vilnius: VU.

42. Toury, G., 1995. Derscriptive Translation Studies and Beyond. Amsterdam/ Philadelphia: John Benjamins. https://doi.org/10.1075/btl.4

43. Trikkonen-Condit, S., 2002. Translationese - a Myth or an Empirical Fact. A Study into the Linguistic Identifiability of Translated Language. Target, 14(2), pp.145-171.

44. Trippel, T., and Zinn, C., 2015. DMPTY - A Wizard for Generating Data Management Plans. CLARIN 2015 Selected Papers. Linköping Electronic Conference Proceedings, no. 123. Prieiga per internetą: http://www.ep.liu. se/ecp/123/006/ecp15123006.pdf [Žiūrèta 2016 m. liepos mèn.].
45. Utka, A. 2004. Phases of Translation Corpus: Compiliation and Analysis. International Journal of CorpusLinguistics 9-2, pp.95-224.

46. Utka, A., Levāne-Petrova, K., Bielinskienè, A., Kovalevskaitè, J., Rimkutè, E., Vēvere, D. 2012. Lithuanian-Latvian-Lithuanian Parallel Corpus. Human Language Technologies The Baltic Perspective. Proceedings of the Fifth International Conference Baltic HLT, pp.260-264.

47. Vaičenonienè, J. 2011. Lithuanian Literature in English. A Corpus-Based Approach to the Translation of Author-Specific Neologisms. (Daktaro disertacija). Kaunas: VDU.

48. Vaičenonienė, J., 2012. Neiprastų kolokacijų vertimas grožinès literatūros kūriniuose: tekstynu paremtas tyrimas. Darbai ir dienos. Kaunas: VDU, pp.117-136.

49. Vaičenonienè, J., 2014. How Relevant is the Distinction between the Original and Translated Texts in General Corpora? Human Language Technologies - The Baltic Perspective. Amsterdam/ Berlin: IOS Press, pp.248-256.

50. Vanderauwera, R., 1985. Dutch Novels Translated into English. The Transformation of a 'Minority' Literature. Amsterdam: Rodopi.

51. Volungevičienè, S., 2013. Kolokacijų vertimo problemos: gretinamoji vokiečių-lietuviu kalbu studija. (Daktaro disertacija). Vilnius: VU.

52. Xiao, R., He, L., Yue, M., 2010. In Pursuit of the Third Code: Using the ZJU Corpus of Translational Chinese in Translation Studies. In: Xiao, R., (ed.), Using Corpora in Contrastive and Translation Studies. Newcastle: Cambridge Scholars, pp.182-214.

53. Xiao, R., 2010. Using Corpora in Contrastive and Translation Studies. Cambridge Scholars Publishing.

54. Zanettin, F., 2012. Translation-Driven Corpora. Corpus Resources for Descriptive and Applied Translation Studies. Manchester: St. Jerome Publishing, pp.47-48.

55. Zanettin, F., 2013. Corpus Methods for Descriptive Translation Studies. Social and Behavioral Sciences, 95, pp.20-32. https://doi. org/10.1016/j.sbspro.2013.10.618 


\section{Šaltiniai}

1. 4th Using Corpora in Contrastive and Translation Studies Conference (UCCTS). Prieiga per internetą: http://ucrel.lancs.ac.uk/uccts4/ past-confs.php [Žiūrèta 2016 m. liepos mèn.].

2. COMPARA: Portuguese - English Parallel Translation Corpus. Prieiga per internetą: https://user.clarin.eu/resources/comparaportuguese-english-parallel-translationcorpus [Žiūrèta 2016 m. liepos mèn.].

3. Dabartinés lietuvių kalbos tekstynas. Prieiga per internetą: http://tekstynas.vdu.lt/ tekstynas/ [Žiūrèta 2016 m. liepos mèn.].

4. Data Management Plan. Prieiga per internetą: http://www.clarin-d.de/en/preparation/datamanagement-plan [Žiūrèta 2016 m. liepos mèn.].

5. Depositing Services. Prieiga per interneta: https://www.clarin.eu/content/depositingservices [Žiūrèta 2016 m. liepos mèn.].

6. English-Italian Translational Corpus (CEXI). Prieiga per internetą: http://universal.elra. info/product_info.php?cPath=37_39\&products_ id=1454 [Žiūrèta 2016 m. liepos mèn.].

7. Informacija apie lygiagretuji tekstynq. Prieiga per internetą: http://tekstynas.vdu.lt/page. xhtml?id=info-about-parallel-corpus [Žiūrèta 2016 m. liepos mèn.].

8. International Accociation for Translation and Cultural Studies (IATIS). Prieiga per internetą: http://www.iatis.org/index.php/iatis-belohorizonte-conference [Žiūrèta 2016 m. liepos mèn.].
9. LILA lygiagretusis tekstynas. Prieiga per internetą: http://tekstynas.vdu.lt/page. xhtml?id=parallelLILA [Žiūrèta 2016 m. liepos mèn.].

10. Linguistic Properties of Translations. A Corpus-Based Investigation for the Language Pair English-German (CROCO). Prieiga per internetą: http://fr46.uni-saarland.de/croco/ index_en.html [Žiūrèta 2016 m. liepos mèn.].

11. Lygiagretusis tekstynas. Prieiga per internetą: http://tekstynas.vdu.lt/page. xhtml?id=parallelCorpus [Žiūrèta $2016 \mathrm{~m}$. liepos mèn.].

12. Non-English, Parallel \& Multilingual Corpora. Prieiga per internetą: https://www.uow.edu. au/ dlee/corpora2.htm [Žiūrèta 2016 m. liepos mèn.].

13. Oslo Multilingual Corpus (OMC). Prieiga per internetą: https://www.hf.uio.no/ilos/english/ services/omc/ [Žiūrèta 2016 m. liepos mèn.].

14. The English-Norwegian Parallel Corpus (ENPC). Prieiga per internetą: http://www. hf.uio.no/ilos/english/services/omc/enpc/ [Žiūrèta $2016 \mathrm{~m}$. liepos mèn.].

15. The ZJU Corpus of Translational Chinese (ZCTC). Prieiga per internetą: http://www. lancaster.ac.uk/fass/projects/corpus/ZCTC/ [Žiūrèta 2016 m. liepos mèn.].

16. Translational English Corpus (TEC)). Prieiga per internetą: https://www2.fgw.vu.nl/ resources/corpora/detail.php?idnr=46 [Žiūrèta 2016 m. liepos mèn.].

\section{Summary}

\section{Jurgita Vaičenonienè, Jolanta Kovalevskaitè, Teresè Ringailienè. Corpus-Based Translation Studies: Research and Resources}

In Corpus Based Translation Studies, it is claimed that there are certain features common to all translated texts which make them different from the originals. The majority of investigations on the features of translations deal with the dominant languages, such as English (Baker, 1993, 1995, 1996; Laviosa, 1997, 1998), German (Kenny, 2001) or Chinese (Xiao et al., 2010). However, it remains unclear whether these features are common to the translations of other typologically different or minor languages. Despite the prevalence of translations, there has been a lack of language resources representative of translated Lithuanian. The aim of this article is to overview major research and resources in Corpus Based Translation Studies and to present a compiled comparable corpus of original and translated Lithuanian. The 4 million word corpus includes fiction and popular science texts, and consists of four sub-corpora (original and translated fiction; original and translated popular science litera- 
ture). It is believed that the created comparable corpus of original and translated Lithuanian will contribute to further research on translations and have a practical value for trainee and professional translators, lecturers and language editors, who will be able to use the publicly available corpus for a comparable search of the language use in original and translated Lithuanian.

\section{Jurgita Vaičenonienè}

Humanitariniu mokslu daktarè, Vytauto Didžiojo universiteto Užsienio kalbų, literatūros ir vertimo studiju katedros lektorè.

\section{Mokslinès veiklos sritys}

Vertimo studijos, vertimo pedagogika, tekstynų lingvistika, diskurso analizè.

\section{Adresas}

Vytauto Didžiojo universitetas, Humanitarinių mokslu fakultetas, Užsienio kalbų, literatūros ir vertimo studiju katedra, V. Putvinskio g. 23-320, LT-44243 Kaunas.

\section{El. paštas:}

jurgita.vaicenoniene@vdu.lt

\section{Jolanta Kovalevskaitẻ}

Humanitarinių mokslu daktarè, Vytauto Didžiojo universiteto Kompiuterinès lingvistikos centro mokslo darbuotoja, Užsienio kalbų, literatūros ir vertimo studiju katedros lektorè.

\section{Mokslinès veiklos sritys}

Tekstynų lingvistika, frazeologija, leksikologija ir leksikografija, terminologija.

\section{Adresas}

Vytauto Didžiojo universitetas, Humanitariniu mokslu fakultetas, Kompiuterinès lingvistikos centras, V. Putvinskio g. 23-216, LT-44243 Kaunas.

\section{El. paštas:}

jolanta.kovalevskaite@vdu.lt

\section{Teresẻ Ringailienẻ}

Humanitariniu mokslų daktarè, Vytauto Didžiojo universiteto Užsienio kalbų, literatūros ir vertimo studijų katedros lektorè.

\section{Mokslinès veiklos sritys}

Multimodalioji diskurso analizè, mokslo populiarinimo ir akademinis diskursas, tekstynu lingvistika, vertimo studijos.

\section{Adresas}

Vytauto Didžiojo universitetas, Humanitarinių mokslu fakultetas, Užsienio kalbu, literatūros ir vertimo studiju katedra, V. Putvinskio g. 23-320, LT-44243 Kaunas.

\section{El. paštas:}

terese.ringailiene@vdu.lt

\section{Apie autores}

